\title{
Strategies to improve physical activity by exercise training in patients with chronic kidney disease
}

This article was published in the following Dove Press journal: International Journal of Nephrology and Renovascular Disease 10 March 2015

Number of times this article has been viewed

\section{Yoshiyuki Morishita Daisuke Nagata}

Division of Nephrology, Department of Internal Medicine, Jichi Medical University, Tochigi, Japan
Correspondence: Yoshiyuki Morishita Division of Nephrology, Department of Internal Medicine, Jichi Medical University, 33II-I, Yakushiji, Shimotsuke, Tochigi 329-0498, Japan

$\mathrm{Tel}+8 \mathrm{I} 285587346$

Fax +8I 285444869

Email ymori@jichi.ac.jp

\begin{abstract}
Decreased physical activity resulting in muscle loss is often observed in patients with chronic kidney disease and is one of the main predictors of mortality in these patients. Exercise training may improve physical activity and prevent muscle loss in patients with chronic kidney disease. Efforts to introduce exercise training to these patients may be clinically beneficial by reducing their mortality rates.
\end{abstract}

Keywords: chronic kidney disease, exercise training, physical activity

\section{Introduction}

Protein-energy wasting $(\mathrm{PEW})$ is a condition in which body stores of protein and energy fuels are reduced. ${ }^{1} \mathrm{PEW}$ is frequently observed in patients with chronic kidney disease (CKD), and its progression has been associated with several factors, including accumulation of uremic toxins, hypermetabolism, acidosis, unresolved inflammation, and nutritional deficiencies. ${ }^{2-4}$ In addition, comorbid conditions, such as diabetic mellitus, heart failure, hypertension, and arteriosclerosis, have been found to contribute to the progression of PEW. ${ }^{4-7} \mathrm{PEW}$ is one of the main factors responsible for reductions in muscle mass and strength and in physical activity, a condition called sarcopenia, in CKD patients. ${ }^{8,9}$ Sarcopenia has been shown to increase the risk of fractures and decrease the quality of life, as well as being a major predictor of mortality, in CKD patients. ${ }^{10-12}$ Therefore, strategies to prevent muscle loss and improve physical activity are important in managing patients with CKD.

Recent evidence has shown that physical function can be improved and muscle loss reduced in all CKD patients, irrespective of stage and treatment modality. ${ }^{13,14}$ Several guidelines, including those of the American College of Sports Medicine (ACSM) and the National Kidney Foundation Kidney Disease Outcome Quality Initiative clinical practice guidelines, recommend regular exercise to prevent muscle loss and improve physical activity in patients with CKD. ${ }^{15,16}$ This review focuses on exercise training strategies to improve physical activity and prevent muscle loss, and the effects of these strategies, in patients with CKD.

\section{Effects of exercise training}

The studies that investigated the effects of exercise training in CKD patients are summarized in Table 1. 
Table I Studies that investigated the effects of exercise training in patients with CKD

\begin{tabular}{|c|c|c|c|c|c|}
\hline Patients & References & $\begin{array}{l}\text { Number of patients } \\
\text { (exercise/control) }\end{array}$ & $\begin{array}{l}\text { Study } \\
\text { duration }\end{array}$ & Exercise training & Outcome \\
\hline \multirow[t]{4}{*}{$\begin{array}{l}\text { CKD patients } \\
\text { not on dialysis }\end{array}$} & $\begin{array}{l}\text { Castaneda } \\
\text { et } \mathrm{al}^{23}\end{array}$ & $14 / 12$ & 12 weeks & Resistance training & $\begin{array}{l}\text { Skeletal muscle hypertrophy. } \\
\text { Decreased C-reactive protein } \\
\text { and interleukin-6 }\end{array}$ \\
\hline & $\begin{array}{l}\text { Pechter } \\
\text { et } \mathrm{al}^{24}\end{array}$ & $17 / 9$ & $\begin{array}{l}\text { I } 2 \text { weeks } \\
\text { (twice a week) }\end{array}$ & $\begin{array}{l}\text { Low-intensity aerobic } \\
\text { exercise training in the } \\
\text { pool twice a week for } \\
30 \text { minutes }\end{array}$ & $\begin{array}{l}\text { Improved cardiopulmonary } \\
\text { functional parameters. } \\
\text { Decreased oxidative } \\
\text { stress, blood pressure, } \\
\text { and proteinuria. Increased } \\
\text { glomerular filtration rate }\end{array}$ \\
\hline & $\begin{array}{l}\text { Castaneda } \\
\text { et } \mathrm{al}^{25}\end{array}$ & $14 / 12$ & $2-8$ weeks & Resistance training & $\begin{array}{l}\text { Increased skeletal muscle mass } \\
\text { and strength. increased serum } \\
\text { prealbumin }\end{array}$ \\
\hline & $\begin{array}{l}\text { Mustata } \\
\text { et } \mathrm{al}^{26}\end{array}$ & $10 / 10$ & 12 months & Exercise training & $\begin{array}{l}\text { Improved } \mathrm{VO}_{2 \text { max }} \text {, exercise } \\
\text { tolerance, and arterial stiffness }\end{array}$ \\
\hline \multirow[t]{4}{*}{$\begin{array}{l}\text { Hemodialysis } \\
\text { patients }\end{array}$} & $\begin{array}{l}\text { Kouidi } \\
\text { et } \mathrm{al}^{33}\end{array}$ & 7 & 6 months & Resistance training & $\begin{array}{l}\text { Improved muscle atrophy; } \\
48 \% \text { increase in } \mathrm{VO}_{2 \max } \\
29 \% \text { increase in exercise time, } \\
\text { increased muscle strength } \\
\text { of the lower limbs }\end{array}$ \\
\hline & $\begin{array}{l}\text { Sakkas } \\
\text { et } \mathrm{al}^{34}\end{array}$ & 9 & 6 months & $\begin{array}{l}\text { Aerobic exercise training } \\
\text { three times per week } \\
\text { for } 6 \text { months }\end{array}$ & $\begin{array}{l}\text { Increased muscle fibers. } \\
\text { Decreased proportion } \\
\text { of atrophic fibers }\end{array}$ \\
\hline & $\begin{array}{l}\text { Painter } \\
\text { et a }{ }^{35}\end{array}$ & 48 & 5 months & $\begin{array}{l}\text { Ergometer exercise } \\
\text { training during } \\
\text { hemodialysis sessions } \\
\text { three times per week }\end{array}$ & $\begin{array}{l}\text { Skeletal muscle hypertrophy. } \\
\text { Decreased levels of serum } \\
\text { C-reactive protein and } \\
\text { interleukin-6 }\end{array}$ \\
\hline & $\begin{array}{l}\text { Konstantinidou } \\
\text { et } \mathrm{al}^{36}\end{array}$ & $\begin{array}{l}36 \\
\text { Group A } 16 \\
\text { Group B } 10 \\
\text { Group C } 10\end{array}$ & 6 months & $\begin{array}{l}\text { A. Supervised exercise } \\
\text { training on nondialysis days } \\
\text { in rehabilitation center } \\
\text { B. Exercise training during } \\
\text { dialysis session } \\
\text { C. Unsupervised exercise } \\
\text { training at home }\end{array}$ & $\begin{array}{l}\text { A. Increases of } 43 \% \text { in } \mathrm{VO}_{2 \max } \\
\text { and } 33 \% \text { in exercise time } \\
\text { B. Increases of } 24 \% \text { in } \mathrm{VO}_{2 \max } \\
\text { and } 22 \% \text { in exercise time } \\
\text { C. Increases of } 17 \% \text { in } \mathrm{VO}_{2 \max } \\
\text { and } 14 \% \text { in exercise time }\end{array}$ \\
\hline $\begin{array}{l}\text { Peritoneal } \\
\text { dialysis patients }\end{array}$ & $\begin{array}{l}\text { Mustata } \\
\text { et } \mathrm{al}^{38}\end{array}$ & 6 & 3 months & Regular exercise training & Improved mental health score \\
\hline
\end{tabular}

Abbreviations: $\mathrm{CKD}$, chronic kidney disease; $\mathrm{VO}_{2 \text { max }}$, maximal oxygen consumption.

\section{CKD patients not on dialysis}

Exercise tolerance and maximal exercise capacity were found to decrease gradually, in accordance with the progression of CKD stage, in patients not on dialysis. ${ }^{17-20}$ Exercise tolerance and maximal exercise capacity started to decrease during early stages of CKD (stage 2), with patients at CKD stages 3-5 showing progressive reductions, averaging $50 \%-80 \%$ when compared with healthy subjects. ${ }^{21,22}$ Previously, exercise training was not recommended for CKD patients not on dialysis because of concerns that exercise training may decrease renal blood flow and glomerular filtration rate and increase the degree of proteinuria, resulting in CKD stage progression. More recently, however, exercise training was reported to show beneficial effects on exercise tolerance and maximal exercise capacity without decreasing renal function in this population. ${ }^{23-26}$ Other beneficial effects of exercise training included improvements in glucose/ lipid metabolism, reductions in inflammation and oxidative stress, and inhibition of catabolism. ${ }^{23-25}$ Exercise training for 12 months was found to improve peak oxygen consumption $\left(\mathrm{VO}_{2 \text { peak }}\right)$, exercise tolerance, and arterial stiffness, ${ }^{26}$ whereas exercise training for 12 weeks was effective in preventing skeletal muscle loss, even in patients on a low-protein diet $\left(0.6 \mathrm{~g} / \mathrm{kg}\right.$ body weight per day) for renoprotection. ${ }^{23}$ Exercise training also significantly increased skeletal muscle mass and strength while reducing markers of inflammation, including serum concentrations of C-reactive protein and interleukin- $6 .{ }^{25}$ Aerobic exercise training in a pool for 30 minutes twice weekly for 12 weeks was found to improve parameters of cardiorespiratory function, as well as reducing oxidative stress markers, without impairing renal disease. ${ }^{24}$ Thus, appropriate exercise training may effectively improve 
physical activity by preventing muscle loss in CKD patients not on dialysis.

\section{Hemodialysis patients}

The decreased physical activity resulting in muscle loss is a crucial factor in the prognosis of patients on hemodialysis. ${ }^{27-29}$ Exercise tolerance was reported to decrease to the same level in hemodialysis patients as in patients with heart failure and chronic obstructive pulmonary disease. ${ }^{30}$ We previously reported that skeletal muscle mass and muscle strength decreased in accordance with duration on hemodialysis, even after adjustment for age and sex. ${ }^{31}$ We also reported that physical activity is positively associated with muscle mass in hemodialysis patients. ${ }^{32} \mathrm{~A}$ questionnaire survey of exercise habits in 2,264 hemodialysis and peritoneal dialysis patients found that 795 (35.1\%) of these patients exercised little or not at all. ${ }^{27}$ These sedentary habits were observed more in older than in younger patients and more in females than in males and tended to be associated with heart and vessel diseases. ${ }^{27}$ The 1-year mortality rate was 1.62 -fold higher in sedentary than in physically active patients. ${ }^{27}$ The Dialysis Outcomes and Practice Pattern Study also reported a negative association between exercise habits and mortality in hemodialysis patients. ${ }^{28}$ The mortality risk was lower in patients with, than without, regular exercise habits (at least once per week), after adjustment for age; sex; race; duration of end-stage renal disease; body mass index; comorbid diseases, including diabetes mellitus, cardiovascular disease, and pulmonary disease; and laboratory measures of serum albumin, phosphate, calcium, creatinine, and hemoglobin concentrations. ${ }^{28}$ Muscle mass, as determined by mid-arm muscle circumference, was positively associated with 5-year mortality rate in 792 hemodialysis patients. ${ }^{29}$ Exercise training has been reported to improve muscle loss and exercise capacity and tolerance, resulting in increased physical activity, in hemodialysis patients. ${ }^{33-36}$ Exercise training at $50 \%-80 \%$ of maximal oxygen consumption $\left(\mathrm{VO}_{2 \text { max }}\right)$, consisting of cycle ergometry or treadmill, followed by aerobic exercises, such as calisthenics or steps, swimming, ball games, low-weight resistance exercises, or stretching exercises, for 6 months in hemodialysis patients was found to improve muscle atrophy and increase $\mathrm{VO}_{2 \max }$ by $48 \%$ and exercise time by $29 \%$, as well as improving peak muscle strength of the lower limbs. ${ }^{33}$ In addition, favorable histological changes were observed in the structure of capillaries and muscle mitochondria. ${ }^{33}$ A second study also reported that aerobic training on a friction-braked cycle ergometer three times per week for 6 months significantly increased muscle fiber in hemodialysis patients, as well as reducing the proportion of atrophic fibers. ${ }^{34}$ In those studies, muscle biopsy samples taken from each patient's leg vastus lateralis or the medial head of the gastrocnemius muscle were cut into transverse sections for histological investigation. ${ }^{33,34}$ Similarly, ergonometric exercise training using stationary cycles during hemodialysis sessions three times per week for 5 months improved $\mathrm{VO}_{2 \text { max }}$ and self-reported physical functioning. ${ }^{35}$ These results suggested that exercise training can prevent muscle loss, resulting in better prognosis, in patients on hemodialysis.

\section{Peritoneal dialysis patients}

Peritoneal dialysis patients may have more time for exercise training than hemodialysis patients because the former are not restricted to a bed during dialysis sessions. In addition, mid-ultrafiltration and dialysis do not result in rapid changes in volume status and electrolytes, thus allowing exercise training. Few studies, however, have focused on the effects of exercise training in peritoneal dialysis patients..$^{37,38}$ Regular exercise training for 3 months in six peritoneal dialysis patients was found to significantly improve mental, but not physical, health conditions, including physical functioning. ${ }^{38}$ Further large-scale, long-term clinical studies are needed to determine the effects of exercise training in peritoneal dialysis patients.

\section{Risks and disadvantages of exercise}

CKD patients may be at increased risks of bone fractures owing to CKD-mineral bone disorder. ${ }^{39,40}$ In addition, CKD patients have many risk factors for cardiovascular disease. ${ }^{41,42}$ These complications in the condition of CKD patients must be carefully evaluated prior to exercise training. The ACSM guidelines recommend that exercise testing of CKD patients be supervised by trained medical personnel and that the clinical status of patients be evaluated before prescribing exercise. ${ }^{16}$ To our knowledge, no study to date has evaluated the risks of exercise in CKD patients. Thus, evaluation of the risks and disadvantages of exercise training in $\mathrm{CKD}$ patients warrants further investigation.

\section{Recommendations for exercise testing and programming Exercise testing}

The ACSM guidelines recommend exercise stress tests, such as treadmill and ergonometric exercise tests, be performed to measure peak oxygen consumption $\left(\mathrm{VO}_{2 \text { peak }}\right)$, thus evaluating the exercise tolerance and maximal exercise capacity of each CKD patient. ${ }^{16}$ Although also recommending repetition maximum tests to evaluate isotonic muscle strength, these guidelines state that one-repetition maximum (1-RM) tests, 
which measure the greatest resistance that can be moved through the full joint in a controlled manner with good posture, be avoided, whereas over 3-RM tests are recommended so as not to cause bone fractures in CKD patients. ${ }^{16}$

\section{Exercise programming}

Aerobic exercise training can be gradually increased in accordance with the increased exercise tolerance of individual patients. Resistance exercise training (2-3 days/week) is also recommended for patients in stable condition. ${ }^{16}$ The ACSM guidelines recommend that all CKD patients (CKD patients not on dialysis, as well as those on hemodialysis and peritoneal dialysis) perform aerobic exercise training at mild to moderate strength $\left(40 \%-60 \%\right.$ of $\left.\mathrm{VO}_{2 \text { peak }}\right)$ for $20-60$ minutes/ day for 3-5 days/week. These guidelines also recommend resistance exercise training for these patients, at 70\%-75\% of one-repetition maximum for a minimum one set of 10-15 repetitions on 2-3 days/week. ${ }^{16}$ The National Kidney Foundation Kidney Disease Outcome Quality Initiative guidelines recommend that hemodialysis patients perform 30 minutes of moderate-intensity exercise on most if not all days per week. ${ }^{15}$ Cochrane collaboration guidelines also recommend $30 \mathrm{~min}-$ utes of exercise three times per week to improve physical fitness, resulting in improved health-related quality of life in hemodialysis patients. ${ }^{43}$ Because these patients are restricted to bed during hemodialysis and their body conditions, such as water-fluid balance and electrolytes, change rapidly from before to after hemodialysis, the ACSM guidelines recommend that exercise training not be performed immediately after dialysis. ${ }^{16}$ These guidelines also recommend that exercise training be performed at an early phase hemodialysis session to prevent hypotension. ${ }^{16}$ A comparison of the effects of exercise training at different times found that patients who exercised on nondialysis days in the rehabilitation center showed a greater increase in exercise training time and $\mathrm{VO}_{2 \text { peak }}$ than patients who exercised during hemodialysis sessions and those who performed unsupervised moderate exercise training at home. ${ }^{36}$ Although peritoneal dialysis patients may attempt to exercise while peritoneal dialysis fluid is present, this may produce discomfort; these patients should then try to exercise after removal of peritoneal dialysis fluid. ${ }^{16}$

\section{Counseling of exercise training for CKD patients}

The National Kidney Foundation Kidney Disease Outcome Quality Initiative clinical practice guidelines recommend that routine care planning for dialysis patients includes assessment of physical functioning and encouraging of patients to participate in physical activity. ${ }^{15}$ The Dialysis Outcomes and Practice Pattern Study reported that a 10\% increase in regular exercise was associated with a $9 \%$ reduction in mortality of dialysis patients. ${ }^{44}$ Thus, exercise counseling is very important in enhancing physical activity and reducing mortality in patients with CKD. The prevalence of CKD has increased, making it a common disease globally. ${ }^{45}$ Appropriate exercise counseling by primary care physicians and nephrologists is crucial in improving patient prognosis. However, little is known about the appropriateness of counseling. We previously reported that exercise recommendations have not yet been widely adopted and are insufficiently recommended by primary care physicians who manage CKD patients, despite the high rate of nutrition counseling. ${ }^{46}$ The main reasons these primary physicians did not recommend exercise training were lack of adequate knowledge on the effects of exercise training and lack of knowledge about guidelines for exercise training. ${ }^{46}$ Primary care physicians should prescribe exercise training, whereas nephrologists and/or physiologists should design programs and evaluate their progress in individual CKD patients. ${ }^{47}$ The cooperative planning and management of exercise training for CKD patients may encourage exercise training by these patients, improving their quality of life and prognosis.

\section{Conclusion}

Decreased physical activity resulting in muscle loss is often observed in CKD patients and is one of the main predictors of mortality in these patients. Appropriate exercise training is important in improving physical activity by preventing muscle loss in CKD patients, improving their quality of life and reducing their mortality rate. Total management, including testing, programming, and counseling for exercise training by medical staff, may encourage exercise training by CKD patients.

\section{Disclosure}

The authors have no conflicts of interest to declare.

\section{References}

1. Fouque D, Kalantar-Zadeh K, Kopple J, et al. A proposed nomenclature and diagnostic criteria for protein-energy wasting in acute and chronic kidney disease. Kidney Int. 2008;73:391-398.

2. Bonanni A, Mannucci I, Verzola D, et al. Protein-energy wasting and mortality in chronic kidney disease. Int $J$ Environ Res Public Health. 2011;8(5):1631-1654.

3. Remuzzi A. Vitamin D, insulin resistance, and renal disease. Kidney Int. 2007;71:96-98.

4. Carrero JJ, Stenvinkel P, Cuppari L, et al. Etiology of the protein-energy wasting syndrome in chronic kidney disease: a consensus statement from the international society of renal nutrition and metabolism (ISRNM). J Ren Nutr. 2013;23:77-90. 
5. Pupim LB, Heimburger O, Qureshi AR, Ikizler TA, Stenvinkel P. Accelerated lean body mass loss in incident chronic dialysis patients with diabetes mellitus. Kidney Int. 2005;68:2368-2374.

6. von Haehling S, Lainscak M, Springer J, Anker SD. Cardiac cachexia: a systematic overview. Pharmacol Ther. 2009;121:227-252.

7. Wang AY, Sea MM, Tang N, et al. Energy intake and expenditure profile in chronic peritoneal dialysis patients complicated with circulatory congestion. Am J Clin Nutr. 2009;90:1179-1184.

8. Carrero JJ, Chmielewski M, Axelsson J, et al. Muscle atrophy, inflammation and clinical outcome in incident and prevalent dialysis patients. Clin Nutr. 2008;27:557-564.

9. Kalantar-Zadeh K, Ikizler TA, Block G, Avram MM, Kopple JD. Malnutrition-inflammation complex syndrome in dialysis patients: causes and consequences. Am J Kidney Dis. 2003;42:864-881.

10. Cheema B, Abas H, Smith B, et al. Investigation of skeletal muscle quantity and quality in end-stage renal disease. Nephrology (Carlton). 2010;15:454-463.

11. Stenvinkel P, Heimburger O, Lindholm B. Wasting, but not malnutrition, predicts cardiovascular mortality in end-stage renal disease Nephrol Dial Transplant. 2004;19:2181-2183.

12. Desmeules S, Levesque R, Jaussent I, Leray-Moragues H, Chalabi L, Canaud B. Creatinine index and lean body mass are excellent predictors of long-term survival in haemodiafiltration patients. Nephrol Dial Transplant. 2004;19:1182-1189.

13. Storer TW, Casaburi R, Sawelson S, Kopple JD. Endurance exercise training during haemodialysis improves strength, power, fatigability and physical performance in maintenance haemodialysis patients. Nephrol Dial Transplant. 2005;20:1429-1437.

14. Heiwe S, Tollback A, Clyne N. Twelve weeks of exercise training increases muscle function and walking capacity in elderly predialysis patients and healthy subjects. Nephron. 2001;88:48-56.

15. K/DOQI Workgroup. K/DOQI clinical practice guidelines for cardiovascular disease in dialysis patients. Am J Kidney Dis. 2005;45: S1-S153.

16. American College of Sports Medicine. ACMS's Guidelines for Exercise Testing and Prescription Medicine. 9th ed. Philadelphia: Lippincott Williams \& Wilkins/Wolters Kluwer Health; 2013.

17. Faria Rde S, Fernandes N, Lovisi JC, et al. Pulmonary function and exercise tolerance are related to disease severity in pre-dialytic patients with chronic kidney disease: a cross-sectional study. BMC Nephrol. 2013;14:184

18. Clyne N, Jogestrand T, Lins LE, Pehrsson SK. Progressive decline in renal function induces a gradual decrease in total hemoglobin and exercise capacity. Nephron. 1994;67:322-326.

19. Boyce ML, Robergs RA, Avasthi PS, et al. Exercise training by individuals with predialysis renal failure: cardiorespiratory endurance, hypertension, and renal function. Am J Kidney Dis. 1997;30:180-192.

20. Odden MC, Whooley MA, Shlipak MG. Association of chronic kidney disease and anemia with physical capacity: the heart and soul study. J Am Soc Nephrol. 2004;15:2908-2915.

21. Leikis MJ, McKenna MJ, Petersen AC, et al. Exercise performance falls over time in patients with chronic kidney disease despite maintenance of hemoglobin concentration. Clin J Am Soc Nephrol. 2006;1:488-495.

22. Eidemak I, Haaber AB, Feldt-Rasmussen B, Kanstrup IL, Strandgaard S Exercise training and the progression of chronic renal failure. Nephron. 1997; 75:36-40.

23. Castaneda C, Gordon PL, Uhlin KL, et al. Resistance training to counteract the catabolism of a low-protein diet in patients with chronic renal insufficiency. A randomized, controlled trial. Ann Intern Med. 2001;135:965-976.

24. Pechter U, Ots M, Mesikepp S, et al. Beneficial effects of water-based exercise in patients with chronic kidney disease. Int $J$ Rehabil Res. 2003;26:153-156.

25. Castaneda C, Gordon PL, Parker RC, Uhlin KL, Roubenoff R, Levey AS. Resistance training to reduce the malnutrition-inflammation complex syndrome of chronic kidney disease. Am J Kidney Dis. 2004;43: 607-616.
26. Mustata S, Groeneveld S, Davidson W, Ford G, Kiland K, Manns B Effects of exercise training on physical impairment, arterial stiffness and health-related quality of life in patients with chronic kidney disease: a pilot study. Int Urol Nephrol. 2011;43:1133-1141.

27. O’Hare AM, Tawney K, Bacchetti P, Johansen KL. Decreased survival among sedentary patients undergoing dialysis: results from the dialysis morbidity and mortality study wave 2. Am J Kidney Dis. 2003;41: 447-454.

28. Tentori F, Elder SJ, Thumma J, et al. Physical exercise among participants in the Dialysis Outcomes and Practice Patterns Study (DOPPS): correlates and associated outcomes. Nephrol Dial Transplant. 2010;25: 3050-3062.

29. Noori N, Kopple JD, Kovesdy CP, et al. Mid-arm muscle circumference and quality of life and survival in maintenance hemodialysis patients. Clin J Am Soc Nephrol. 2010;5:2258-2268.

30. Painter P. Physical functioning in end-stage renal disease patients: update 2005. Hemodial Int. 2005;9:218-235.

31. Morishita Y, Kubo K, Haga Y, et al. Skeletal muscle loss is negatively associated with single-pool $\mathrm{Kt} / \mathrm{V}$ and dialysis duration in hemodialysis patients. Ther Apher Dial. 2014;18:612-617.

32. Morishita Y, Kubo K, Miki A, Ishibashi K, Kusano E, Nagata D. Positive association of vigorous and moderate physical activity volumes with skeletal muscle mass but not bone density or metabolism markers in hemodialysis patients. Int Urol Nephrol. 2014;46:633-639.

33. Kouidi E, Albani M, Natsis K, et al. The effects of exercise training on muscle atrophy in haemodialysis patients. Nephrol Dial Transplant. 1998;13:685-699.

34. Sakkas GK, Sargeant AJ, Mercer TH, et al. Changes in muscle morphology in dialysis patients after 6 months of aerobic exercise training. Nephrol Dial Transplant. 2003;18:1854-1861.

35. Painter P, Moore G, Carlson L, et al. Effects of exercise training plus normalization of hematocrit on exercise capacity and health-related quality of life. Am J Kidney Dis. 2002;39:257-265.

36. Konstantinidou E, Koukouvou G, Kouidi E, Deligiannis A, Tourkantonis A. Exercise training in patients with end-stage renal disease on hemodialysis: comparison of three rehabilitation programs. J Rehabil Med. 2002;34:40-45.

37. Ling KW, Wong FS, Chan WK, et al. Effect of a home exercise program based on Tai Chi in patients with end-stage renal disease. Perit Dial Int. 2003;23(Suppl 2):S99-S103.

38. Mustata S, Cooper L, Langrick N, Simon N, Jassal SV, Oreopoulos DG. The effect of a Tai Chi exercise program on quality of life in patients on peritoneal dialysis: a pilot study. Perit Dial Int. 2005;25:291-294.

39. Block GA, Klassen PS, Lazarus JM, Ofsthun N, Lowrie EG, Chertow GM. Mineral metabolism, mortality, and morbidity in maintenance hemodialysis. J Am Soc Nephrol. 2004;15:2208-2218.

40. Kalantar-Zadeh K, Kuwae N, Regidor DL, et al. Survival predictability of time-varying indicators of bone disease in maintenance hemodialysis patients. Kidney Int. 2006;70:771-780.

41. Agarwal R, Nissenson AR, Batlle D, Coyne DW, Trout JR, Warnock DG. Prevalence, treatment, and control of hypertension in chronic hemodialysis patients in the United States. Am J Med. 2003;115:291-297.

42. Zanchetta JR, Bogado CE. Raloxifene reverses bone loss in postmenopausal women with mild asymptomatic primary hyperparathyroidism. J Bone Miner Res. 2001;16:189-190.

43. Heiwe S, Jacobson SH. Exercise training for adults with chronic kidney disease. Cochrane Database Syst Rev. 2011;10:CD003236.

44. Tentori F. Mortality risk among hemodialysis patients receiving different vitamin D analogs. Kidney Int. 2006;70:1858-1865.

45. Jha V, Garcia-Garcia G, Iseki K, et al. Chronic kidney disease: global dimension and perspectives. Lancet. 2013;382:260-272.

46. Morishita Y, Miki A, Okada M, et al. Exercise counseling of primary care physicians in metabolic syndrome and cardiovascular diseases is associated with their specialty and exercise habits. Int J Gen Med. 2014;7:277-283.

47. Clyne N. Exercise training in chronic kidney disease. US Nephrol. 2011;5:3. 


\section{Publish your work in this journal}

The International Journal of Nephrology and Renovascular Disease is an international, peer-reviewed open-access journal focusing on the pathophysiology of the kidney and vascular supply. Epidemiology, screening, diagnosis, and treatment interventions are covered as well as basic science, biochemical and immunological studies. The journal welcomes

original research, clinical studies, reviews \& evaluations, expert opinion and commentary, case reports and extended reports. The manuscript management system is completely online and includes a very quick and fair peerreview system, which is all easy to use. Visit http://www.dovepress.com/ testimonials.php to read real quotes from published authors.

Submit your manuscript here: http://www.dovepress.com/international-journal-of-nephrology-and-renovascular-disease-journal 